\title{
REVIEW
}

\section{Recessive disorders - a serious health hazard?}

\author{
Jindřich Č́ítek and Barbora Bláhová \\ Department of Genetics, Animal Breeding and Nutrition, Faculty of Agriculture, University of South \\ Bohemia, České Budějovice, Czech Republic
}

Received $17^{\text {th }}$ September 2004.

Revised $12^{\text {th }}$ October 2004.

Published online $4^{\text {th }}$ November 2004.

\begin{abstract}
Summary
The aim of this study is to summarize new findings on the most important recessive hereditary disorders in cattle. Important diseases in cattle breeding are: BLAD (Bovine Leukocyte Adhesion Deficiency), DUMPS (Deficiency of Uridine - 5-Monophosphate Synthase), MSUD (Maple Syrup Urine Disease), Bovine Citrullinaemia, and - not detected until 2000 - CVM (Complex Vertebral Malformation). Some of these disorders occur also in man. Thanks to the intensive exploitation of elite sires in artificial insemination, the risk of a fast spread world-wide of recessive hereditary defects is extremely high. In animals there are methods for the detection of heterozygotes like test mating, but they are inapplicable in man due to ethical considerations. Molecular genetic methods enable early diagnosis in man, and are useful in genetic counselling. In animals, the detection of heterozygotes enables their selection and therefore the control and prevention of the spread of recessive diseases in the population. The use of new molecular technologies promises quick progress in animal bioechnology.
\end{abstract}

Keywords: genetic disorders - cattle - CVM - BLAD - DUMPS - MSUD - citrullinaemia

\section{INTRODUCTION}

Genetic disorders are hereditarily caused physical or functional anomalies of the norm with a negative impact on vitality. In animals, an important effect is a decrease in or loss of performance (DGfZ, 1986).

Lately, many genetically caused human diseases have been described at molecular level, and their respective genes have been sequenced and localised. As most disorders are recessive, new technologies have made it possible to discover heterozygous carriers. Prenatal diagnosis in women has become possible, and abortion induced, if acceptable. Also relevant is the enhancement of genetic counselling in affected families.

In animals, genetic disorders are the focus of attention of breeders, and their occurrence has been monitored for decades. In the USA, for example the Holstein Association initiated a program in 1957 to identify carriers of undesirable recessives and since then has maintained records permitting it to identify animals that carry an undesirable recessive for a physiological abnormality, biochemical defect or enzyme deficiency. At this time, there are identification records for Bulldog (achondroplasia 1, 2 \& 3), Mule Foot (syndactylism), Bovine Leukocyte Adhesion Deficiency (BLAD), Complex Vertebral Malformation (CVM), Prolonged Gestation, Hairless, Dwarfism, Imperfect Skin, Deficiency of Uridine Monophosphate Synthase (DUMPS) and Pink Tooth (congenital porphyria).

In most cases, mutated recessive genes are the reason for genetic disease in breeding animals (Zabek and Rys 1998). The occurrence of the 
recessive mutation requires the presence of two mutated recessive genes in the genotype of an affected animal. Therefore, the after-effects could appear decades after. In context, there would be benefits in limiting inbreeding, and in enlarging the number of elite bulls used in artificial insemination, because long term-diversity depends on relationships between bulls entering AI programs. US bulls born in 1998-99 were related to cow populations by 13.1 for Ayrshires, and 10:1 for Holsteins, respectively. Five sires fathered $100 \%$ of Ayrshire bulls, and $42 \%$ of Holsteins. Internationally, ten sires in Interbull countries in 1995 fathered $54 \%$ of Ayrshires, and $43 \%$ of Holsteins. Maternal diversity is also limited, five sires fathered $45 \%$ of elite US Ayrshire cows, and $17 \%$ of Holsteins (Weigel 2001).

When widely used elite sires producing large quantities of calves turn out, in retrospect, to have been carriers of a defective gene, the consequences are very negative, and the inbreeding in the population intensifies the process. This is what happened in the case of the major genetic defect, BLAD. The bull almost completely responsible for its spread throughout the Holstein breed was Carlin-M Ivanhoe Bell, who has over 79000 daughters with official production records in the USDA system and over 1200 sons with daughters (Olson 2002). The same bull, Bell, was also a carrier of the new genetic defect, CVM. In the case of BLAD, the defective gene was passed on to Bell from his grandsire, Osborndale Ivanhoe, through his sire, Pennstate Ivanhoe Star. It has been determined that Ivanhoe Star was also heterozygous for CVM, probably having received it from his dam. Thus, half of the progeny of Bell were heterozygous for BLAD, and half were heterozygous for CVM. The diseases did not start to reveal themselves until years later when male descendants of Bell were bred to his female descendants.

Because new methodological approaches and molecular technologies have been applied in animals for years, the geneticists have efficient tools for the eradication of genetic disorders in animal populations. So the breeders can manage their breeding herds on the assumption that respected analytical methods of molecular genetics are at their disposal. Knowledge acquired in human genetics could well be applied in animals. In the Czech Republic, sires are tested routinely for BLAD and CVM. Nevertheless, genetic disorders are not the particular focus of geneticists, and experimental results are not published.

To fill the information gap, to recapitulate recent findings and to give some theoretical background, this article reviews the important recessive inherited diseases: Complex Vertebral Malformation, Deficiency of Uridine Monophosphate Synthase, Bovine Citrullinaemia,
Maple Syrup Urine Disease, and Bovine Leukocyte Adhesion Deficiency.

\section{COMPLEX VERTEBRAL MALFORMATION}

Complex Vertebral Malformation (CVM) was first described in Denmark in October 2000 in Holstein calves. In summer 2001 researchers at the Danish Institute of Agriculture Sciences identified the gene and the mutation causing this disease. The defect can be traced back to the American elite sire Carlin-M Ivanhoe Bell. Bell was formerly used extensively world wide and a global impact on the mortality of Holstein calves is inevitable (Konersmann 2002, Konersmann et al. 2003). Recently, his father Penstate Ivanhoe Star USA 1441440, born 20.1.1963 was also found to be a carrier.

This defect is caused by a mutation in an autosomal recessive gene (Revell 2001, Bendixen 2001a, http:/www.naab-css.org/education/ CVMpressrelease-D.html, Snoj 2002). Calves that have one defective gene will appear physically normal, and their performance will be unaffected, but they will be CVM carriers. Animals found to be carriers will be identified with the code " $\mathrm{CV}$ " on all pedigrees and similar lineage statements, and those found not to be carriers will be identified with the code "TV". These codes are expected to be standardised internationally (http://www. naab-css.org/education/CVMpressrelease-D.html, Grzybowski, 2003).

Typical signs of CVM are a shortened neck and forelimbs, bilateral, symmetrical, moderate contraction of the carpal joints, severe contraction and slight lateral rotation of the fetlock joints. The hind limbs show marked bilateral, symmetrical contraction of the fetlocks, with medial rotation of distal limbs. Elongation of the tarsus is also present in both limbs. Vertebral abnormalities are confined to fusion of the last two cervical vertebrae and distortion of the first three thoracic vertebrae, giving a slight scoliosis at that point. Examination of the heart reveals a right-sided hypertrophy and an upper interventricular septal defect. Both the aorta and pulmonary artery originate from the right side of the heart. Cardiac abnormalities of this nature occur in some 50 per cent of cases (Revell 2001, Pazdera 2001, Agerholm et al. 2001, Duncan et al. 2001, Nagahata et al. 2002). Bendixen (2001b) reported that more than 63000 cows have shown several fertility traits associated with the foetal CVM status. Many CVM foetuses are aborted at gestation day 159, while other CVM calves are prematurely born and usually stillborn (Agerholm et al. 2001). Nielsen et al. (2003) reported that if the foetus is homogenous for CVM, $29 \%$ of the cows will abort before gestation day 
100 increasing to $45 \%$ at day 150 , and at day 260 , $77 \%$ of the foetuses will have been aborted.

The method of detecting CVM carriers is based on molecular genetic detection methods (Pazdera 2001).

Sire Carlin-M Ivanhoe Bell and his offspring were used in many countries including the Czech Republic. At present, 74 sires were confirmed as carriers of CVM malformations (e. g. Jabot, Etazon Lord Lily, KOL Nixon, T Klassy, NJY Hubert, Tornedo etc.). In the Czech Republic, an improvement is expected by the adoption of the prudent arrangement whereby the Holstein Cattle Breeders' Association of the Czech Republic and Czech-Moravian Breeding Association publish a list of the sires which are carriers of the CVM factor.

\section{DEFICIENCY OF URIDINE MONOPHOSPHATE SYNTHASE}

Deficiency of Uridine - 5'-Monophosphate Synthase (DUMPS) is a genetic disorder, which interferes with pyrimidine biosynthesis and is inherited as a single, two-allele, autosomal locus (Shanks and Greiner 1992, Kuhn and Shanks 1994). The enzyme uridine - 5'-monophosphate (UMP) synthase catalyses the conversion of orotic acid to UMP, the precursor of all other pyrimidine nucleotides and a normal constituent in the milk of cows and other ruminants (Shanks and Robinson 1989, Shanks et al. 1989). This inherited deficiency of the enzyme has been identified in humans as an autosomal recessive condition called hereditary orotic aciduria. DUMPS has also been observed among dairy cattle, especially in United States Holstein-Friesian cattle (Shanks et al. 1987, Shanks and Robinson 1989). It was observed that several cows in the University of Illinois dairy herd produced in their milk five- to ten-times higher concentrations of orotic acid than normal. These elevations of milk orotic acid were evident at all stages of lactation and persisted from one lactation to the next. The orotic acid was also elevated in the urine and blood of these animals when they were lactating. Some authors hypothesised that if the enzyme UMP synthase was deficient, orotic acid would accumulate (Robinson and Shanks 1990).

UMP synthase is necessary for the de novo synthesis of pyrimidine nucleotides, which are constituents of DNA and RNA. Growth and development of the homozygous recessive is arrested, leading to embryonic mortality around 40 days post - conception (Shanks and Robinson 1990, Robinson et al. 1993). Heterozygous animals carry a defective allele causing DUMPS (Harlizius et al. 1996).
On average half of the offspring of crosses between heterozygotes and normal animals are normal, the other half are carriers. Heterozygous carriers of the defect are routinely identified by measuring the activity of the enzyme UMP synthase in erythrocytes. Such activity in the liver, spleen, kidney, muscle and mammary gland is relatively decreased (Shanks 1990) to about half of the normal value (Schwenger et al. 1994, Robinson and Shanks 1990).

The practical effect of this disorder is that carrier cows show a higher rate of return to service, because some of their pregnancies end in early natural abortion (Fries and Ruvinsky 1999).

The genomic structure of the UMP synthase gene was determined and a PCR-based diagnostic test for carrier detection has been established. DUMPS is caused by point mutation (C-T) at codon 405 within exon 5 (Viana et al. 1998). The UMP synthase gene was mapped to the bovine chromosome 1 (q31-36) (Harlizius et al. 1996).

A possible method of genotyping is given by Schwenger et al. (1993), Grzybowski et al. (1998). A 108-bp product surrounding the mutation was amplified from genomic DNA with primers 5'GCA AAT GGC TGA AGA ACA TTC TG3' and 5'GCT TCT AAC TGA ACT CCT CGA GT3'. The PCR product was digested with Aval; normal homozygote shows bands of 53, 36, and $19 \mathrm{bp}$, heterozygote of $89,53,36$, and $19 \mathrm{bp}$, the recessive genotype is 89 and $19 \mathrm{bp}$.

The designation "DP" is added to the name of known heterozygotes and appears on official pedigrees, while "TD" designates animals that have tested normal for the condition (Shanks and Robinson 1990).

\section{BOVINE CITRULLINAEMIA}

Citrullinaemia is an autosomal recessive error of urea metabolism characterised by high levels of citrulline, and more seriously, of ammonia in plasma, as a result of a deficiency of activity of the urea cycle enzyme, argininosuccinate synthase (ASS). Bovine citrullinaemia is caused by a transition of Cytosine - Thymine at codon 86 within exon 5 in the gene coding for ASS (Padeeri et al. 1999). Normal bovine ASS is a peptide containing 412 amino acids, the disorder was first described in man, then in dogs and was reported in Friesian calves (Healy et al. 1990, www.angis.org.au, Viana et al. 1998). Affected (homozygous) calves are unable to excrete ammonia and display neurological symptoms that become progressively worse, leading to death within one week of birth (Grupe et al. 1996, Lin et al. 2001). 
Padeeri et al. (1999) amplified ASS locus by PCR and detected the mutation at codon 86 by restriction digestion of amplified products. The reaction contained sense 5'GGC CAG GGA CCG TGT TCA TTG AGG ACA TC3' and antisense primers 5'TTC CTG GGA CCC CGT GAG ACA CAT ACT TG3'. The amplified products were digested with AvalI restriction enzyme; the heterozygote showed 185, 103, and $82 \mathrm{bp}$ fragments, and the normal genotype was 103 and $82 \mathrm{bp}$. Viana et al. (1998) used other primers, after cleaving by AvaII the normal homozygote showed 99 and 78bp, heterozygote 177,99 , and 78bp, and recessive homozygote $177 \mathrm{bp}$.

\section{MAPLE SYRUP URINE DISEASE}

Maple Syrup Urine Disease (MSUD) is a lethal, autosomal recessive condition (Healy and Dennis 1995). MSUD results from a deficiency of the $\alpha$ ketoacid dehydrogenase (BCK dehydrogenase) and this error of metabolism is characterised by accumulation of the branched-chain amino acids (leucine, isoleucine and valine), and their respective keto acids (ketoisocaproic acid, keto- $\beta$ methylvaleric acid and ketoisocaproic acid). MSUD has been identified in both man and cattle. MSUD is rare in the human population but relatively common in Poll Hereford and possibly Hereford calves in Australia and Canada, and may be present in the USA and the UK (Harper et al. 1989, Zhang et al. 1990, Healy and Dennis 1995 Dennis and Healy 1999).

Within 12-48h, affected calves develop central nervous system depression, lethargy and a "scruffy" unclean coat, progressing to coma and death within 48-72h (Fries and Ruvinsky 1999).

Healy et al. (1991) described the clinical signs and pathological findings in Poll Shorthorn calves affected by MSUD. The calves were reported to be normal at birth, then developed a progressive neurological disease expressed as a lack of coordination, inability to rise, paddling of the limbs and, terminally, lateral recumbency with opisthotonos. In calves there was widespread vacuolation of white matter, particularly in myelinated tracts of the cerebellum, cerebrum and brain stem. The diagnosis can be confirmed by finding elevated concentrations of branched-chain amino acids in serum, plasma, CSF, ocular fluid or brain tissue.

The mutation is a substitution of cytosine with thymine ( $\underline{C} A G$ to $\underline{T} A G)$, transition exon 2 that converts glutamine (Q) codon (-6) to a stop (ST) codon in the leader peptide sequence for the E1 $\alpha$ subunit of BCK dehydrogenase in Polled Hereford calves with MSUD (Zhang et al. 1990).
Primers used to amplify DNA across codon -6 are EMAI 001 (5'AGC ACC CCC ACA GGT GG3') and that is identical to the sequence of the 5 'end of exon 2 but is preceded by $\mathrm{AG}$, a consensus terminal intron sequence. The antisense primer EMAI 002 (5'CCT CTG GGA TTC ATA GAG GAT GCG G3') is complementary to the sequence at the $3^{\prime}$ end of exon 3. Cytosin or thymine were additional bases at the 3 'end of EMAI 001 to create the normal (EMAI 031; 5'AGC ACC CCC ACA GGT GGC3') and mutant (EMAI 032; 5'AGC ACC CCC ACA GGT GGT3') sense primers used for allele-specific amplification.

The other method used to identify this genetic defect is allele-specific hybridization. For this method the wildtype oligonucleotide 5'ACA GGT GGC AGC AAC3' are used which is complementary to the antisense normal sequence. The mutant oligonucleotide 5'TGT TGC TAC CAC CTG3' is complementary to the sense mutant sequence. Hybridization is detected using a commercial kit. The results of allele-specific amplification studies are consistent with those of allele-specific hybridization (Healy and Dennis 1994).

\section{BOVINE LEUKOCYTE ADHESION DEFICIENCY}

Bovine Leukocyte Adhesion Deficiency (BLAD) is a lethal autosomal recessive disease in Holstein cattle characterized by a greatly reduced level of expression of the $\beta 2$ heterodimeric integrin. Integrins are adhesion molecules that mediate the entry and passage of neutrophiles across membranes to destroy invading pathogens (Kehrli et al. 1992, Poli et al. 1996, Natonek 2000). The $\beta 2$ integrins are classified as CD11/CD18 by the world health organisation according to their $\alpha$ and $\beta$ subunits. They are composed of identical $\beta$ subunits (CD18) and $\alpha$ subunits that vary in structure and are designated as CD11a, CD11b and CD11c for integrins LFA-1, Mac-1 and p150, 95, respectively. Because $\beta 2$ integrin expression requires intracellular association of the CD11 and CD18 subunits, defects in CD18 prevent expression of all $\beta 2$ integrins. It was observed that neutrophils isolated from the BLAD - affected calf had decreased the expression of leukocyte integrins on their cell surface, decreased the ability to aggregate in response to chemotactic stimuli, and also decreased the ability to migrate across bovine endothelial cell monolayers (Pareek and Kaminski 1996).

The defective leukocyte adherence leads to inadequate mucosal immunity and BLAD affected cattle have severe and recurrent mucosal 
infections such as pneumonia, ulcerative gingivitis, periodontitis, papillomatosis, dermatophytosis, loss of teeth, impaired pus formation, delayed wound healing, and stunted growth (Nagahata et al. 1993, 1994, 1997, Ackermann et al. 1996, Ribeiro et al. 2000).

Blood test results from affected calves reveal persistent, marked leukocytosis consisting predominantly of segmented neutrophils. The migration of neutrophils and chemotactic responses was found to be severely impaired. The adherence activities and phagocytosis of yeast particules were markedly diminished, indicating an association with impaired phagocytosing ability of neutrophils via $\mathrm{iC} 3 \mathrm{~b}$ receptor. Markedly diminished amounts of CD18 on neutrophils from affected calves were detected in fluorescence histograms (Nagahata et al. 1994). Gourreau et al. (1998a) related hypoalbuminaemia and hyperglobulinaemia in BLAD animals. Hypoglycaemia is also frequent. Jorgensen and Madsen (1997) observed poorer feed utilization, a tendency to grow more slowly, and a lower incidence of disease treatments in carriers of BLAD. The other observations showed that BL/TL cows, i. e. carriers of BLAD mutation, yielded more milk in the first lactation and more milk protein than their non-carrier half-sisters (Lubieniecki et al. 1999). On the contrary, Fésüs et al. (1999) did not confirm statistically significant differences in production traits between BL and TL type cows.

The molecular basis of BLAD is a single point mutation (A-G) at position 383 in the cDNA of the CD18 gene. This mutation results in a substitution of a glycine for an aspartic acid at position 128 in the protein D128G (Shuster et al. 1992, Jorgensen et al.1993, Gerardi 1996, Rutten et al. 1996, Meylan et al. 1997). Viana et al. (1998) and Shuster et al. (1992) also described the existence of the silent point mutation $(\mathrm{C}-\mathrm{T})$ at position 775 in the cDNA without phenotypic manifestation. DNA studies with the use of restriction endonuclease TaqI or HaeIII detected differences between healthy and affected calves. Gerardi (1996) observed in regard to the method used that normal animals have fragments of 100, 200 and $300 \mathrm{bp}$, and the BLAD - calves have 200 and $400 \mathrm{bp}$ bands. Viana et al. (1998) described the length of fragments for normal animals (191, 152bp), for BLAD carriers (343, 191 and $152 \mathrm{bp})$, and for affected animals (343bp).

The codes for BLAD carriers are "BL" and "TL" for animals found to be free of the BLAD allele (Tainturier et al. 1995, Powell et al. 1996, Simon et al. 1998, Gourreau et al. 1998a,b).

Amplification reactions of the DNA samples were prepared with primers (forward primer 5'CCC TGC CAG TCC AGC TGG ACA CC3', reverse primer - 5'CCA CGC CCA TCA TTC TGG GGC AG3'). The amplified product was digested with restriction enzyme TaqI or HaeIII (Viana et al. 1998, Ribeiro et al. 2000).

\section{CONCLUSION}

To answer the above question, recessive inherited disorders cause some fatal or heavy nociceptive conditions. In animals, they can in some cases significantly influence the economics of breeding. The massive spread of genetic defects in cattle like CVM or BLAD in recent years is caused by the extensive use of elite sires, and latent heterozygous carriers. Mutations as a cause of bad genes cannot be excluded, and the creation of new defects is enabled by the properties of DNA. Artificial insemination accelerates the spread of undesirable recessives world-wide. However, the new methods of molecular genetics enable us to find the cause at gene level. They make it possible to detect heterozygous animals, to control the genetic health of the population, and in a way, to anticipate the cumulation of recessive alleles. The transfer of molecular methods into animal research, and the exploitation of conserved chromosomal fragments in comparative mapping promise quick progress in animal bioechnology.

\section{ACKNOWLEDGEMENT}

The work was supported by Ministry of Agriculture of the Czech Republic, project NAZV QF3012.

\section{REFERENCES}

Ackermann M.R., M.E. Kehrli, J.A. Laufer, L.T. Nusz: Alimentary and respiratory tract lesions in eight medically fragile Holstein cattle with bovine leukocyte adhesion deficiency (BLAD). Vet. Pathol. 33: 273-281, 1996.

Agerholm J.S., C. Bendixen, O. Andersen, J. Arnbjerg: Complex vertebral malformation in Holstein calves. J. Vet. Diagn. Invest. 13: 283289, 2001.

Bendixen C.: The CVM -mutation is not restricted to descendants of the American Holstein Friesian bull- Carlin-M Ivanhoe Bell. http:// www cattle.dk/holstein/pres0111.htm, 2001a.

Bendixen C.: Danish scientists reveal the gene responsible for CVM, a lethal heritable defect in Holstein Cattle. http://www.lr.dk/Kvaeg/ diverse/PRESS-uk.htm 2001b.

Dennis J.A. and P.J. Healy: Definition of the mutation responsible for maple syrup urine disease in poll shorthorns and genotyping poll 
shorthorns and poll herefords for maple syrup urine disease alleles. Res. Vet. Sci., 67: 1-6, 1999.

DGfZ: Empfehlungen zur Beruecksichtigung von Erbfehlern in der Tierzucht. Zuechtungskunde, 58: 151-153, 1986.

Duncan R.B., C.B. Carrig, J.S. Agerholm, C. Bendixen: Brief communications. Complex vertebral malformation in a Holstein calf: report of a case in the USA. J. Vet. Diagn. Invest., 13: 333-336, 2001.

Fésüs L., A. Zsolnai, I. Anton, I. Bárány, S. Bozó: Short Communication. BLAD genotypes and cows production traits in Hungarian Holsteins. J. Anim. Breed. Genet., 116: 169-174, 1999.

Fries R., A. Ruvinsky: The Genetics of Cattle. CAB International. Wallingford. 1999, pp 710.

Gerardi A.S.: Bovine leukocyte adhesion deficiency: a brief overview of a modern disease and its implications. Folia Vet. 40: 6569, 1996.

Gourreau J.M., L. Vander Massen, R. Braque: Le défaut d'adhérence des leucocytes chez les bovins (BLAD). Le Point Vet. 29: 67-74, 1998a.

Gourreau J.M., L. Vander Massen, R. Braque: Trois cas cliniques de BLAD. Le Point Vet. 29: 75-76, 1998b.

Grupe S., G. Dietl, M. Schwerin: Population survey of citrullinemia on German Holsteins. Livest. Prod. Sci. 45: 35-38, 1996.

Grzybowski, G.: Zespol znieksztalceń kregoslupa jego konsekwencje w hodowli bydla. Med. Wet. 59: 107-111, 2003.

Grzybowski G., T. Grzybowski, M. Wozniak, I. Chacinska-Buczek, E. Smuda, K. Lubieniecki: Badania przesiewowe na obecność genu wczesnej obumieralności zarodków DUMPS u bydla w Polsce. Med. Wet. 54: 189-193, 1998.

Harper P., J.A. Dennis, P.J. Healy, G.K. Brown: Maple syrup urine disease in calves: a clinical, pathological and biochemical study. Austr. Vet. J. 66: 46-49, 1989.

Harlizius B., S. Schröber, I. Tammen, D. Simon: Isolation of the bovine uridine monophosphate synthase gene to identify the molecular basis of DUMPS in cattle. J. Anim. Breed. Genet. 113: 303-309, 1996.

Healy P.J. and J.A. Dennis: Molecular heterogeneity for bovine maple syrup urine disease. Anim. Genet. 25: 329-332, 1994.

Healy P.J. and J.A. Dennis: Heterozygote detection for maple syrup urine disease in cattle. Austr. Vet. J. 72: 346-348, 1995.

Healy P.J., J.A. Dennis, P.A.W. Harper, R. Graham, R.E. Reuter: Maple syrup urine disease in Poll Shorthorn calves. Austr. Vet. J. 69: 143, 1991.
Healy P.J., P.A.W. Harper, J.A. Dennis: Bovine citrullinaemia: a clinical, pathological, biochemical and genetic study. Austr. Vet. J. 67: 255-258, 1990.

Jorgensen J.N. and P. Madsen: Genetic parameters for and BLAD effects on beef production traits and diseases frequency. Acta Agric. Scand. A, Anim. Sci. 47: 1-8, 1997.

Jorgensen C.B., J.S. Agerholm, J. Pedersen, P.D. Thomsen: Bovine leukocyte adhesion deficiency in Danish Hosltein-Friesian Cattle. I. PCR screening and allele frequency Estimation. Acta Vet. Scand. 34: 231-236, 1993.

Kehrli M.E., D.E. Shuster, M.R. Ackermann: Leukocyte adhesion deficiency among Holstein cattle. Cornell. Vet. 82: 103-109, 1992.

Konersmann Y., W. Wemheuer, B. Brenig: Origin, distribution and relevance of the CVM defect within the Holstein - Friesian population. Zuechtungskunde 75: 9-15, 2003.

Konersmann Y.: Herkunft, Verbreitung und Bedeutung des CVM-Gendefektes in der Holstein-Frisian-Population. Masterarbeit, Georg-August Universität Göttingen. 2002, 89 pp.

Kuhn M.T. and R.D. Shanks: Association of deficiency of uridine monophosphate synthase with production and reproduction. J. Dairy Sci. 77: 589-597, 1994.

Lin D.Y., Y.C. Huang, J.C. Chen, T.W. Yang, T.F. Shiao, H.L. Chang: Investigation of citrullinaemia of dairy cattle in Taiwan. J. Taiwan Livest. Res. 34: 279-284, 2001.

Lubieniecki K., G. Grzybowski, M. Lukaszewicz, J. Lubieniecki: Association between the presence of allele $\mathrm{BL}$ in the genome of dairy cows and their productivity. Anim. Sci. Papers Rep. 17: 189 - 194, 1999.

Meylan M., R. Abegg, H. Sager, T.W. Jungi, J. Martig: Fallvorstellung: Bovine LeukozytenAdhäsions-Defizienz (BLAD) in der Schweiz. Schweiz. Arch. Tierheilk. 139: 277-281, 1997.

Nagahata H., K. Hatakeyama, H. Noda, H. Nochi, K. Tamoto: Two cases of Holstein calves with bovine leukocyte adhesion deficiency (BLAD). Dtsch. Tierärztl. Wschr. 101: 53-56, 1994.

Nagahata H., T. Miura, K. Tagaki, M. Othake, H. Noda, T. Yasuda, K. Nioka: Prevalence and Allele Frequency Estimation of Bovine Leukocyte Adhesion Deficiency (BLAD) in Holstein-Friesian Cattle in Japan. J. Vet. Med. Sci. 59: 233-238, 1997.

Nagahata H., H. Nochi, K. Tamoto, H. Taniyama, H. Noda, M. Morita, M. Kanamaki, G.J. Kociba: Bovine Leukocyte Adhesion Deficiency in Holstein Cattle. Can. J. Vet. Res. 57: 255-261, 1993.

Nagahata H., H. Oota, A. Nitanai, S. Oikawa, H. Higuchi, T. Nakade, T. Kurosawa, 
M. Morita, H. Ogawa: Complex vertebral malformation in a stillborn Holstein calf in Japan. J. Vet. Med. Sci. 64: 1107-1112, 2002.

Natonek M.: Identyfikacja mutacji BLAD u bydla metoda PCR-RFLP. Biul. Inform. 38: 29-33, 2000.

Nielsen U.S., G.P. Aamand, O. Andersen, C. Bendixen, V.H. Nielsen, J.S. Agerholm: Effects of complex vertebral malformation on fertility traits in Holstein cattle. Livest. Prod. Sci. 79: 233-238, 2003.

Olson T.: New genes: Good and Bad. http://dairy. ifas. ufl. du/ floridadairyproductionconference /.2002/ new\% 20genes.pdf, 2002.

Padeeri M., K. Vijaykumar, S. Grupe, M.P. Narayan, M. Schwerin, M.H. Kumar: Incidence of hereditary Citrullinaemia and bovine leucocyte adhesion deficiency syndrome in Indian dairy cattle (Bos taurus, Bos indicus) and buffalo (Bubalus Bubalis) Population. Arch. Tierz. 42: 347-352, 1999.

Pareek C.S. and S. Kaminski: Bovine leukocyte adhesion deficiency (BLAD) and its worldwide prevalence. J. Appl. Genet. 37: 299-311, 1996.

Pazdera J.: CVM - letální porucha u skotu. Náš chov, 4, 23-24, 2001.

Poli M.A., R. Dewey, L. Semorile, M.E. Lozano, C.G. Albarino, V. Romanowski, O. Grau: PCR screening for carriers of bovine leukocyte adhesion deficiency (BLAD) and uridine monophosphate synthase (DUMPS) in argentine Holstein cattle. J. Vet. Med. A. 43: 163-168, 1996.

Powell R.L., H.D. Norman, C.M. Cowan: Relationship of bovine leukocyte adhesion deficiency with genetic merit for performance traits. J. Dairy Sci. 79: 895-899, 1996.

Revell S.: Complex vertebral malformation in a Holstein calf in the UK. Vet. Rec. 24: 659-660, 2001.

Ribeiro L.A., E.E. Baron, M.L. Martinez, L.L. Coutinho: PCR screening and allele frequency estimation of bovine leucocyte adhesion deficiency in Holstein and Gir cattle in Brazil. Genet. Mol. Biol. 23: 831-834, 2000.

Robinson J.L., R.D. Shanks: Review. The inherited deficiency of uridine monophosphate synthase in dairy cattle. J. CAAS 1: 1-4, 1990.

Robinson J.L., R.G. Popp, R.D. Shanks, A. Oosterhof, J.H. Veerkamp: Testing for deficiency of uridine monophosphate synthase among Holstein-Frisian cattle of North America and Europe. Livest. Prod. Sci. 36: 287-298, 1993.

Rutten V.P.M.G., A. Hoek, K.E. Müller: Identification of monoclonal antibodies with specificity to $\alpha$ - or $\beta$ - chains of $\beta_{2}$ - integrins using peripheral blood leucocytes of normal and Bovine Leucocyte Adhesion Deficient (BLAD) cattle. Vet. Immun. Immunopathol. 52: 341$345,1996$.

Schwenger B., S. Schröber, D. Simon: DUMPS cattle carry a point mutation in the uridine monophosphate synthase gene. Genomics 16: 241-244, 1993.

Schwenger B., I. Tamen, C. Aurich: Detection of the homogenous recessive genotype for deficiency of uridine monophosphate synthase by DNA typing among bovine embryos produced in vitro. J. Reprod. Fert. 100: 511514, 1994.

Shanks R.D.: Reproductive consequences of deficiency of uridine monophosphate synthase in Holstein cattle. Am. J. Vet. Res. 51: 800802, 1990.

Shanks R.D., D.ST.A. Bragg, E.P. Barton: Uridine Monophosphate synthase of Jersey Bulls. J. Dairy Sci. 72: 722-725, 1989.

Shanks R.D., D.ST.A. Bragg, J.L. Robinson: Deficiency of uridine monophosphate synthase in Holstein cattle: inheritance and body measurements. J. Anim. Sci. 64: 695-700, 1987.

Shanks R.D., M.M. Greiner: Relationship between genetic merit of Holstein bulls and deficiency of uridine $-5^{\prime}$-monophosphate synthase. J. Dairy Sci. 75: 2023-2029, 1992.

Shanks R.D., J.L. Robinson: Embryonic mortality attributed to inherited deficiency of uridine monophosphate synthase. J. Dairy Sci. 72: 3035-3039, 1989.

Shanks R.D. and J.L. Robinson: Deficiency of uridine monophosphate synthase among Holstein cattle. Cornell. Vet. 80: 119-122, 1990.

Shuster D.E., M.E. Kehrli, M.R. Ackermann, R.O. Gilbert: Identification and prevalence of a genetic defect that causes leucocyte adhesion deficiency in Holstein cattle. PNAS 80: 9225 9229, 1992.

Simon A., D. Le Goic, I. Breyton, A. Douart, J. Lecoanet: Syndrome de Déficiene d'Adhésion des Leucocytes Bovins (DALB): a propos d'une observation clinique. Point Vet. 29: 83-86, 1998.

Snoj T.: Kompleksna vertebralne malformacija pri teletih črno-bele pasme. Vet. Nov. 28: 197-199, 2002.

Tainturier D., L. Grobet, B. Brouwers, J.-F. Bruyas, F. Fieni, I. Battut, J. Lecoanet, A. Douart, I. Breyton, P. Duclos: Bovine Leucocyte Adhesion Deficiency (BLAD): a propos de trois observations cliniques. Revue Méd. Vét. 146: 189-193, 1995.

Viana J.L., A. Fernandez, A. Iglesias, G. Santamarina: Diagnóstico y control de las principales enfermedades genéticas (citrulinemia, DUMPS y BLAD) descritas en 
ganado Holstein-Frisón. Med. Vet. 15: 538544, 1998.

Weigel K.A.: Limiting the consequences of inbreeding in dairy cattle breeding programs. In: 52nd Annual Meeting of the EAAP, Budapest, Hungary, 2001, 74.

Zabek T. and A. Rys: Gene defect in farm animals. Biul. Inform. Inst. Zootech. 36: 5-13, 1998.
Zhang B., P.J. Healy, Y. Zhao, D.W. Crabb, R.A. Harris: Premature translation termination of the pre-E1 $\alpha$ subunit of the branched chain $\alpha$-ketoacid dehydrogenase as a cause of maple syrup urine disease in polled hereford calves. J. Biol. Chem. 265: 2425-2427, 1990.

\section{Address:}

Jindřich Čítek, Department of Genetics, Animal Breeding and Nutrition, Faculty of Agriculture, University of South Bohemia, Studentská 13, 37005 České Budějovice, Czech Republic; citek@zf.jcu.cz 